\title{
Article
}

\section{Evaluating the Nigerian Prosperity Gospel as a Mixed Ideology}

Omavuebe, Augustine Igho

Available at http://clok.uclan.ac.uk/37360/

Omavuebe, Augustine Igho (2021) Evaluating the Nigerian Prosperity Gospel as a Mixed Ideology. Missiology, 49 (4). pp. 389-401. ISSN 0091-8296

It is advisable to refer to the publisher's version if you intend to cite from the work. http://dx.doi.org/10.1177/00918296211011732

For more information about UCLan's research in this area go to http://www.uclan.ac.uk/researchgroups/ and search for < name of research Group>.

For information about Research generally at UCLan please go to http://www.uclan.ac.uk/research/

All outputs in CLoK are protected by Intellectual Property Rights law, including Copyright law. Copyright, IPR and Moral Rights for the works on this site are retained by the individual authors and/or other copyright owners. Terms and conditions for use of this material are defined in the policies page.

\section{CLoK}

Central Lancashire online Knowledge www.clok.uclan.ac.uk

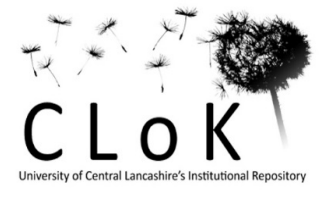




\section{Evaluating the Nigerian Prosperity Gospel as a Mixed Ideology.}

\section{Abstract}

There are two popular suggestions as to how prosperity gospel emerged in Nigeria. The first school of thought posits that the phenomenon of prosperity gospel was exclusively an American ideology imported into Nigeria, while the second view holds that it was entirely an African ideology nurtured with African ingredients and popularised in African soil.

There has not been a respectable number of literatures that actively and adequately explored the Nigerian prosperity gospel as a combination of American prosperity gospel and Nigerian Pentecostal revivalism. Therefore, to fill this literature gap, this article suggests that the Nigerian prosperity gospel is a joint theology with elements of American prosperity gospel ideology which has its origin in American New Thought Movement and Nigerian Pentecostal revivalism which has its origin in Nigerian Indigenous Pentecostal Movement. This attempt employs a historical approach. In this vein, the historical narrative explores related literatures about prosperity gospel in Nigeria and offers a radical shift from the popular views that solely attribute the emergence of prosperity gospel ideology to either Nigerian indigenous Pentecostal revivalism or American prosperity theology.

\section{Introduction}

The concept of prosperity gospel is the theology of all- inclusive success. It is anchored on God's full earthly blessings. It is understood as that Christian teaching that emphasises all-round physical well-being such as good health, financial success, prestige, personal empowerment, long life, peace, and happiness. It propagates all-round prosperity without recourse to suffering. It is the gospel that advertises itself as a divine armament against unemployment, poverty, failure, disease, barrenness, and insecurity (Phillips, 2013; Ehioghae and Olanrewaju, 2015 and Pickering, 2013).

The concept of prosperity gospel is interpreted based on the concept of blessing in the Old Testament and the concept of salvation in the New Testament. God's promises of wealth, security, peace, offspring to Adam and Eve in the Garden of Eden, to Noah and his children after the great flood and to Abraham and his chosen children of Israel in the Old Testament are appropriated to back up prosperity gospel teachings (Pickering, 2013). Similarly, adherents of prosperity 
gospel believe that salvation brought by the death and victory of resurrection of Jesus Christ in New Testament has brought liberation from all social-economic challenges (Amechi, 2014).

Since the advent of prosperity gospel in Nigeria, it has penetrated the religious space with great speed and audacity. Though the phenomenon of prosperity gospel started from the Pentecostal circle, it has cut across barriers. Prosperity messages has been widespread in mainstream Missionary, Pentecostal, and Charismatic Churches in varying degrees in Africa. Prosperity theology was made to travel internationally. The religious strand that began in Nigeria was exported abroad through the utilisation of miracle crusades, mass media such as television, radio, printed posters, and leaflets. Prosperity message penetrated and conquered the African religious landscape. It is currently estimated that more than half of Christian believers in sub-Sahara Africa are subscribers to prosperity gospel ideology (Magbadelo, 2004 and Folarin, 2006).

The popularity of the phenomenon of prosperity gospel has made it to be subjected to historical analysis. From different scholarly evaluations, there seem to be two popular suggestions as to how prosperity gospel appeared in Nigeria. The first school of thought posits that prosperity gospel was entirely an American ideology imported and pioneered by Archbishop Benson Idahosa in the 1970s after he was influenced by it as a student in "Christ for the Nations Bible Institute" in the United States of America (Achunike, 2007 and Kituase, 2017). Scholars in this line of thinking, suggest that Idahosa's adoption of prosperity gospel was related to his life of hardship during his youthful days and his ambition to become successful. They cement their argument by suggesting that Idahosa's ambition of success was catalysed by his exposure to prosperity exponents whom he adopted as mentors in the United State of America (Kitause, 2017). This view does not recognise the impact of indigenous Pentecostal revivalism on the development of prosperity gospel ideology in Nigeria.

In contrast, the second popular view as to the origin of prosperity gospel ideology opines that Nigerian prosperity gospel originated in Africa by African Charismatic Movements of the 1980s. Such views are advanced by Gifford (1990), Kalu (2000) and Gaiya (2002) and subscribed to by Ojo (2013) and Onwu (2006). These scholars suggest that emphasis on prosperity preaching was a response to social-economic changes of the 1980 s created by negative impacts 
of International Monetary fund (IMF) and Structural Adjustment Program (SAP). In the 1980s, IMF and World Bank had required developing nations to create conditions that were beneficial to Western corporations and governments. These conditions were known as Structural Adjustment Programs (SAP). SAP's requirement was for government to cut public spending, these included subsidy for medical care, food, and education. Government in Africa responded by cutting back on government policies and programmes that helped the downtrodden, poor, women, children, and other defenceless groups in society during the widespread Structural Adjustment Programme (SAP) of the 1980s. Thus, according to Gifford (1990), Kalu (2000) and Gaiya (2002), Ojo (2013) and Onwu (2006), the directed change created new social-economic challenges which became precursors to the rise of prosperity gospel in Africa. This view exclusively attributes the emergence of prosperity gospel phenomenon in Nigeria to indigenous Pentecostal revivalism.

Therefore, this article is an attempt to propound a more appealing view where it is noted that the history of prosperity gospel in Nigeria is fluid and complicated and that Nigerian prosperity gospel has elements of African Pentecostal (charismatic) revivalism and America word of faith movement and positive thinking. In this study, attempt is made to supply a detailed narrative, which investigates the origins of Nigerian Pentecostal revivalism and American prosperity gospel and the amalgamating point between Nigerian Pentecostal revivalism and American prosperity gospel. Subsequently, the implications of the Nigerian mixed spirituality are suggested.

\section{Origin of Nigerian Pentecostal Revivalism.}

Pentecostal revivalism was a phenomenon that was internally motivated in Nigeria (Kalu, 2000). It started with activities of Garrick Braide, an Anglican lay preacher in 1912. Pentecostal revivalism was initiated as a direct response to the failure of European missionaries to advance a Christian gospel that was adaptive to the African context and cultural orientation (Olofinjana, 2012). Nigerian Pentecostal revivalism originated as a quest for a Christian tradition that could be interpreted through African cosmological understanding. European missionaries had propagated a Christian tradition that was wrapped up and coloured with Western cultures (Magbadelo, 2004). The Christian message was not indigenised to suit the spiritual needs and aspirations of Africans. Foreign languages such as English and Latin were adopted for church 
services instead of indigenous languages. This non-inclusive and Westernised Christianity seemed alien to Africans, thereby making the native tribes to have the feeling of unacceptability (Omavuebe, 2017).

Furthermore, the exhibition of superiority complex and white supremacy tendency could not allow European missionaries to see anything good about African indigenous cultures, thereby not abhorring the devaluation of indigenous cultural dispositions. Africans and their indigenous cultures were degraded and termed "savages" who were living in a barbaric stage of human existence who must accept the white man's culture and value system to be civilised. In this thinking, the primitive African cultures must be discarded to embrace Europeanisation. This was visible in both material and non-material aspect of cultures. To become Christians, Africans were made to take up European names and African organisational systems were modelled according to that of Europe. The being of the colonised Africans had to be replaced with the being of the European colonisers. To this end, the colonised felt rejected and disrespected, a development that created a vacuum for the advancement of another brand of Christianity that was interpreted through African cosmological orientation (Isichei, 1995).

It is important to note that African cosmology was highly sacralised. The visible and the invisible worlds were inseparable. The spirit world was said to control the physical world. What happened in the material world was determined by what happened in the world of the spirit. Evil forces were said to inhabit the spirit world and were believed to possess power to control the affairs of humanity. Everything that happened to human beings whether good or bad was attributed to the action of a spirit being. The total life of the African was like going through a cosmic battle. This was the battle of how to succeed amidst evil forces and tendencies. The question of power and how to succeed amidst evil machination was unavoidable in African cosmology. Europeans missionaries responded by avoiding the question of power and cosmic battle by building charity and educational institutions, and pointed Africans to the God of love who was seated far above the heavens, a distant God that could not fight Africans' daily battles of evil plotting. This approach which could not answer the question of power to win cosmic battles left the field to be fertilised for the rise of indigenous revivalism (Kalu, 2002). 
The catalyst to indigenous revivalism in Nigeria was Garick Sokari Braide in 1912. Braide's emphasis was on the power of God for divine healing and victory over satanic forces. He campaigned that believer must be prayerful and holy to overcome evil forces. The religious ideology that surrounded Braide's Movement was victory over evil forces. In 1916, Braide's revival campaign gave birth to the Aladura Churches and the Christ Army Church which were the pioneer Pentecostal Churches in Nigeria (Gaiya, 2002 and Olofinjana, 2012). Between 1920 and 1947, another wave of revival emerged within the Aladura Movement. The exponents of this revival were: Joseph Babalola, the founder of Christ Apostolic Church, Samuel Oshoffa, the founder of Celestial Church of Christ, Moses Orimolade Tunolase and Christiana Abiodun, the founders of Cherubim and Seraphim Church, and Oshitelu, the founder of Church of the Lord (Tuner, 1967). There is a change in the character of every indigenous religious revolution in every decade and every generation, depending on the contextual circumstances of the people (Rotimi, Nwadialor and Ugwuja, 2016). The religious ideology that drove this revival within the Aladura Movement was fasting, prayer and divine healing. There was an outbreak of an incurable influenza in Yoruba land in 1918. Desperate need for a cure for the deadly influenza that eluded missionary medicine pushed the Aladura Movement into fasting and prayer, seeking the face of God for a divine solution. As what might be defined as heavenly intervention in affairs of humankind, the deadly influenza stopped, and many lives were saved (Isichei, 1995). Though there is no scientific evidence to show the correlation between the prayer offered and the disappearance of the influenza virus, three possibilities are insinuated. The influenza viruses are classified into four types - types A, B, C and D. Strands A and $B$ are suggested to be responsible for causing epidemic of seasonal disease, particularly during the winter season (flu season) as in the West and raining season as in Africa. The strand C of the influenza virus is only known to cause mild illness and are believed not to be responsible for flu epidemic. The $D$ type of the influenza virus is only known to cause infection in cattle and not humans ( Szretter, Balish, and Katz, 2006 and Cohen, et al, 2014). Thus, as there were no vaccines in 1918 that could have immunised people against the virus, the first possible explanation to the disappearance of the influenza virus could be the change of season, which created unfavourable condition for the striving of the virus. The second reality could be that people might have developed natural immunity towards the virus because of prolonged exposure. The third possibility is the intervention of immortality in humanity. The bible is saturated with 
incidences of God intervening in the affairs of His people - He healed Naaman of his leprosy; He healed Job of his infectious boils; Jesus healed a woman with an issue of blood; Jesus healed ten lepers (2Kings 5:1-14; Job 42: 10-17; Luke 8:43-48, 17: 11-19). Strengthened by what they believed was divine intervention, the Aladura Movement famously spread across Nigeria. With the emphasis on prayer, fasting and divine healing, the emerging indigenous groups started having more Pentecostal directions (Isichei, 1995).

As the Aladura Revival Churches were growing in popularity and spreading rapidly, there was a simultaneous hostility from Europeans missionaries who felt threatened by the audacity of the movements. The quest for legitimisation and protection from persecution of Missionary Churches led by colonial authority, compelled the Aladura Churches to invite other Pentecostal movements such as Assemblies of God Church from America, Four Gospel Church from North America, and Apostolic Church from Britain. It was an alliance that led to another wave of revivalism between 1960s and 1970s. American preachers such as Billy Graham, Tommy Lee Osborn and Morris Cerullo and British preachers such as John Stott got involved in organising great gospel campaign that brought about massive conversion of people in their open-air gospel crusades (Kalu, 2008). The religious ideology changed from fasting, praying, and healing to repentance, personal encounter with the Holy Spirit and speaking in tongues. This Pentecostal revival saw the emergence of such interdenominational Christian groups as the Christian Union (CU), Scripture Union (SU) and Christian Student Movement in Colleges and Universities of Nigeria. Students of Colleges and Universities of higher learning who encountered the inspiring messages of personal regeneration and the work of the Holy Spirit in the life of the believer started creating a worship space for themselves where they could express their newly acquired gifts of the Holy Spirit. The influx of audio messages, Christian tracts and books from America aided the stability of the charismatic renewal. Strengthened by the new wave of revival, students who caught fire of the revival embarked on intensive and extensive evangelism to spread the gospel of Jesus Christ to the unreached (Kalu, 2008 and 2010). In 1970s, Idahosa, one of the University students who later became a pioneer agent of another brand of revivalism known as prosperity gospel within the Pentecostal faith was part of this revival campaign.

In 1972, Idahosa founded the Church of God Mission with its headquarters in Benin City of Nigeria; the ideological foundation of Idahosa's church was all- 
inclusive prosperity. Earthly possession was the focus of Idahosa's teachings. To achieve prosperity, Idahosa contended that Christians must be born again, possess the power of the Holy Spirit, be delivered from demonic forces, make positive confessions, exercise faith in word of God and as well engage in faith seed, tithes, giving of offerings and donation. Today, Idahosa is considered as the father of prosperity gospel in Nigeria (Florin, 2007 and Kituase, 2017). However, it is expedient to note that Idahosa's prosperity gospel was a combination of elements of African Pentecostal revivalism and American word of faith and positive confession movement. Idahosa picked the ingredients of Nigerian Pentecostal revivalism such as being born again, power of the Holy Spirit, victory over satanic forces and exorcism, and combined it with that of American word of faith and positive confession he encountered while studying as a student in the United States of America (Folarin, 2007 and Kitause, 2017).

\section{Origin of American prosperity gospel.}

Quantifying the prosperity gospel ideology in America is not so simple. American root of prosperity gospel as expressed through word of faith and positive declaration is long and complicated. It emerged from the New Thought Movement in the nineteenth century which was popular with such non-religious exponents as Ralph Emerson who propounded that there was a causal relationship between human thoughts and experiences, and that individual possessed thought power which could be exercised over the material world. In the late nineteenth and early twentieth centuries, the idea of the individual thought power influenced E. W. Kenyon who put a Christian coloration to it (Bowler,2013). Kenyon suggested that Christians should always harbour positive thoughts in their mind. He argued that people should stop thinking or saying negative things that related to poverty or sickness about themselves. Kenyon's prescription was that people should embark on saying positive things associated with health, success, and prosperity. This reliance on individual mind power was to transform thought and words into blessings sent from heaven. Kenyon became a link to the famous prosperity gospellers who laid the foundation of modern prosperity gospel ideology (Bowler,2013). Normal Vincent Peale, a pastor of Marble Collegiate Church in New York introduced a modern ingredient to the teachings of New Thought Movement with his popular book, "The Power of Positive Thinking" in 1952. Peale contended that when the believer engaged in positive thinking, he set in motion positive forces or power that produced positively amazing results. Modern prosperity gospel advocates such as Oral 
Roberts mixed the elements of positive declaration with Pentecostal teaching about physical and unwavering demonstration of faith in receiving miraculous healing and material wealth, promoted by Kenneth Hagin through his word of faith campaigns to produce the theology of all-round success in the late twentieth century. This theology of all-round success was widely adopted and spread by Pentecostal television preachers in 1950s. It was a short change from the Pentecostal idea of baptism of the Holy Spirit and speaking in tongues earlier pioneered by Charles F. Parham and popularised by Seymour, W. J. in 1912 to faith prosperity. America's first Pentecostal televangelists in the 1950s and 1960 s created a succession of prosperity gospellers who utilised the media to reach out to a growing audience across the globe. These believers were challenged to donate to the church to get a seven-fold blessing in return (Oral, 1970; Kenyon, 2004 and Bowler, 2013).

The analysis is that, the American prosperity gospel as it is, has its origin in the New Thought Movement characterised by positive declaration and word of faith phenomenon characterised by physical healing, material wealth and all-round physical wellbeing (Bowler, 2013). Exponents of prosperity gospel speculate that to achieve all-round physical blessing, believers must engage in positive thought, positive confession, and financial donations to their churches (Oral, 1970 and Kenyon, 2004).

\section{The meeting point between Nigerian Pentecostal revivalism and American prosperity gospel.}

In 1972, Benson Idahosa enrolled for theological training in Christ for the Nations Bible Institute, United States of America. It was during this period Idahosa personally encountered the American prosperity gospel through his exposure to American prosperity gospel preachers such as Oral Roberts, Kenneth Hagin, T.L. Osborn, and Jim Baker who influenced his life, Christian views, and ministry tremendously (Achunike, 2007). The result was his eventful adoption of the prosperity gospel which was indigenised to suit the Nigerian cultural belief in the existence of demonic entities and the prevailing economic difficulties (Okwori, 1995). The Nigerian cosmological belief acknowledged the ability of demonic forces to stop one's good fortune in life (Kalu, 2000). The Nigerian prevailing economic difficulties in the 1970s was the result of the effects of three years of civil unrest that has ravaged economic life and subsequent government failure to squarely address these difficulties (Nafziger, 
1972). Social-economic challenges such as poverty, sickness and poor health facility, insecurity, unemployment, high mortality rate, and infrastructural decay were the basic precursors for the audacious and rapid spread of the prosperity gospel in Africa in general and in Nigeria in particular. The emphasis on all-round financial success, peace, poverty alleviation, self-empowerment, longevity, divine security, and divine healing helped the rapid spread of the prosperity gospel. As social-economic challenges such as unemployment, sickness, high mortality rate and lack of basic amenities remained, and as there was quick fix promises, and as well as there was persistent perception that deity was capable of solving one's human challenges and protecting the devotee from evil machinations, prosperity gospel flourished because it provided a spirituality that had immediate solution to prevailing social-economic challenges (Oyakhilome, 2019). To this end, it appealed not just to victims of social-economic difficulties caused by three years of civil unrest and subsequent political exploitation, but to those who were motivated by the quest for divine protection, healing, and provision, or motivated by the drive for upward economic mobility (Kalu, 2000; Magbadelo, 2005; Falorin, 2006 and Kitause and Achunike, 2015). In this vein, it is not out of place to subscribe to the hypothesis of Maxwel (1998) that religion of hope shines brighter during human challenges. Similarly, Illogu (1974) posits that religious movement strives in the time of social-economic challenges. Where contextual challenges hold sway, there is the probability that people tend to quickly accept and adopt contextual theology model that speaks to their condition. Hence, it was for this reason that many Africans, most especially Nigerians wanted to overcome or escape poverty, unemployment, or sickness by embracing the gospel of prosperity in the 1970s (Kalu, 2000; Magbadelo, 2005; Falorin, 2006 and Kitause and Achunike, 2015).

Thus, the indigenised theology of success was composed using the ingredients of the prevailing social-economic hardship, the African cosmological orientation of demonology, witchcraft, wizardry, and God's supreme power to deliver the victims of terrestrial oppression to make it more contextual and appealing to Nigerians. God was presented as liberator who could simultaneously liberate Christians from evil forces which were presumed to have mitigated their success in life and from the prevailing social-economic challenges faced by the individual Christian (Rotimi, Nwadialor and Ugwuja, 2016 and Kitause, 2017). The fundamentals for attaining a successful life were to be born again, possess the power of the Holy Spirit, cast out demons of failure and engage in faith-giving, positive confession, and faith healing. To this end, Idahosa combined the 
elements of American prosperity gospel, featured in donation, positive confession, seed-faith, word of faith, and faith healing with the Nigerian Pentecostal revivalism, featured in regeneration, power of Holy Spirit in life of believers, power of God over satanic forces and deliverance from demonic power (Oral, 1970; Kalu, 2000 and Oyakhilome, 2018). This was the meeting point between American prosperity gospel and Nigerian Pentecostal revivalism. Like contextual theology, the imported elements of American prosperity gospel phenomenon were indigenised with the prevailing elements of Nigerian indigenous Pentecostal theology. In this persuasion, it is appropriately appealing to disagree with Gifford (1990) and Achunike (2007) who posited that the Nigerian prosperity gospel was entirely a foreign element and Kalu (2000), Gaiya (2002), Ojo (2013) and Onwu (2006) who exclusively attributed the advent of prosperity gospel in Nigeria to African indigenous Pentecostal revivalism. It is in this sense; the Nigerian prosperity gospel is described as a mixture of elements of American prosperity theology and Nigerian indigenous Pentecostal revivalism.

The Nigerian amalgamated prosperity gospel ideology espoused by Idahosa resulted in the frequent visits of first generation and second generation of prosperity gospel preachers like Oral Roberts, T L. Osborn, and Benny Hinn from America to Nigeria in the 1980s on the invitation of Idahosa (Kitause, 2017). Why Idahosa adopted prosperity gospel could best be described in three tiers: his personal experience of tough economic realities, his belief in a universe inhabited by evil mercenaries, capable of thwarting one's success in life, and his feeling of an omnipotent God who was able to subdue evil forces and abundantly bless His subjects. The harsh social-economic atmosphere created by three years of Nigerian civil war which lasted from 1967 to 1970 and subsequent government failure to swiftly address these challenges created a hard social-economic terrain where Idahosa grew up which deprived him certain life pleasures. The excruciating experience created in him the passion to overcome poverty. While studying as a student in United States of America, the prosperity gospel appealed to his curiosity, context, and belief (Kitause, 2017). It was, therefore, an opportunity to adopt new spirituality as the American prosperity theology was emphasising poverty alleviation and all-round success. There he met with a God who was said to be interested in not just the financial viability of humankind, but all-inclusive success of believers. This was the God of happiness, personal empowerment, and all-round success; only what the 
individual needed to do was to engage in positive confession, visualisation, faithseed sowing and expect a hundred-fold returns of material blessing.

The second reason Idahosa adopted prosperity gospel was his orientation with the African religious cosmos. Within African religious universe, spirit are forces which can be mastered for effective performance by a good mastery of spiritual processes and the use of the right invocations by whoever that controls them. This is where the magicians and diviners who are gifted in the invocations of spirits can either use them for the good of the society such as inner peace, mediation, civil justice, harmony with nature or for the bad of the community such as causing drought in farming season; wrecking mysterious havoc to one's crops or animals, resulting in great economic meltdown; or causing strange sicknesses and deaths. The African belief system sees everything from the eyes of the spirit. Social-economic challenges are often linked with the actions of evil powers.

With Idahosa's personal experience of harsh social-economic environment and the impacts of his African cosmological belief in evil mercenaries capable of mitigating one's material prosperity, and his belief in an all-powerful Christian God, he started articulating the model of his mixed theology of success, using the elements of Nigerian Pentecostal revivalism and of American prosperity gospel. The American prosperity gospel with its central emphasis on material wealth appealed to his personal experience of social-economic challenges while the Nigerian indigenous Pentecostal revivalism addressed his fears of demonic agents, capable of mitigating his personal success. This action made him to be regarded as the pioneer of prosperity gospel in Nigeria and other African countries (Flarin, 2006 and 2007).

Idahosa's adopted of prosperity gospel could be summed up in the phrase- "live big because you have a big God." He reiterated that it was God's will for Christians to be emancipated from power, shackles, and influence of poverty to a life of abundant wealth, health and all-inclusive blessings in Christ Jesus who has conquered the spirit of limitation through death and resurrection. In this thinking, he believed that Christians were worshipping a rich and powerful God who never intended poverty, sickness, unemployment, or sudden death for humanity (Achunike, 2007). He claimed that God could supply all humanity's need according to His riches in glory (Philippians 4:19). What Christians needed to do was to ask whatever they wanted, and God in His infinite mercy and 
goodness would supply it. He posited that believers should honour God with their resources, and they would become prosperous in all areas of their lives. Idahosa demonstrated his belief in prosperity gospel with his lifestyle. This was shown in his flamboyant dressing, use of the best of cars, and engagement in massive projects with big budgetary allocations (Rotimi, Nwadialor and Ugwuja, 2016). Idahosa also believed that there were demonic agents who possessed human being to perpetuate evil against Christians. These agents were believed to be the cause of human misery, calamities, failures, and sicknesses. He upheld that such agents could be conquered when the believer possessed power of God which was ultimate. He maintained that this power was an endowment from the Holy Spirit when the believer was born again. Born again here meant being lifted from poverty to riches. Idahosa assumed that a born-again Christian was a conquering Christian who through power of God engaged in frontal attack on demonic power responsible for human adversity. Idahosa's prosperity teachings reached out to things that permeated the here and now of the African people. Evidence abounded of Nigerian Christians who attended his camps, crusades, church services primarily in search of healing, prosperity, employment, and victory over evil forces that they believed were militating against their success (Rotimi, Nwadialor and Ugwuja, 2016).

Today, the mixed prosperity gospel ideology initiated by Idahosa has become so popular that you hardly hear any message from the pulpit without emphasis on material prosperity. At the heart of this amalgamated theology is the notion that the liberating power of salvation is not something for the past, but for the here and now, and should take place in any human condition that is characterised by social-economic challenges. In this light, the Nigerian prosperity gospel theology assumes that the church has centred its message on the soul of man for too long. The church is presumed to have failed to address the social-economic plight of man. What is clear from prosperity gospel advocacy is that salvation is not entirely about deliverance from the Adamic sin or atonement for the inability of the believer to meet the standard of God as advocated by the church, but it is more about everyday realities of life. It is more about how the believer can succeed in business, how to be healed of any ailment, how to bear children, how to live a long life, how to have enough money to solve basic issues of life and how to be happy in life (Gutierrez, 1974 and Amechi, 2014).

However, to activate or to claim these social-economic blessings, exponents of prosperity gospel posit that the Christian must through faith engage in financial 
giving, positive declaration, visualisation and as well as exorcism (Oral, 1970 and Oyakhilome, 2018). In this sense, Prosperity theology views the relationship between God and Christians as transactional. The transactional relationship is a contract between God and believers: Like the transactional process where money is exchanged for good and services, the individual Christian must give his money, demonstrate his faith, and engage in positive thinking, visualization, confession and as well cast out demons responsible for failure to show his allegiance to God to receive perfectly amazing all-round blessings in concrete manner. Nigerian prosperity theology posits that for this religious transaction to succeed, the believer must fulfil the transactional elements (faith, giving, positive confession, visualization, and exorcism) of the contract and God must give prosperity to the individual Christian in return to keep to part of His covenant (Kwateng-Yeboah, 2017).

The implications of Nigerian prosperity gospel.

There seems to be a lacuna created in Nigerian prosperity model. It does not subscribe to the ideas captured by Max Weber in his: "The Protestant Ethic and the Spirit of Capitalism," where he argued that the industrial revolution in Europe was propelled by the fundamental principles emphasised by Protestant teachings. Weberian model depicts a causal link between religious practices and social-economic prosperity. The model assumes that for real prosperity to occur, emphasis must be laid on basic principles such as accountability, honesty, hardwork, integrity, perseverance, delayed gratification that underpin socialeconomic development (Carr, 2003). On the other hand, the Nigerian model envisages an extremely powerful God who can solve all contextual difficulties by fiat. It presents a 'bread and butter' kind of life (a rosy and easy life), where the adherent is presented with a simplistic journey, void of challenges. Human responsibilities are thus pushed to a deity. It also espouses a world where witchcraft or magic, whether real or imagined are used to explain the cause of predicament such as illness, poverty, unemployment, accident, and natural disasters. It extremely becomes anathema and a horrifying reality that excuses the impacts of moral human choice in attaining prosperity. The Nigerian prosperity theology is also used to explain away political leadership failure, diverting attention from one of the obvious causes of social-economic crisis in the society. Prosperity gospel spirituality closes the door against exploring other possibilities such as human choice and a failed political system as being responsible for social tragedies such as poverty, high mortality rate, sickness, 
unemployment, incessant road accidents, and blames it on imagined spiritual agencies.

However, the Nigerian spirituality is a new way of rethinking about God. For the victims of social-economic failure, there is a new understanding of God. Adherents reject the traditional mind-set that focuses on eschatological things. Thus, they opt for a new way by which adherents can perceive God from the standpoint of hope in present anxieties. Like the Pharisees and Sadducees who hoped for a Jesus that would save the Israelites from Roman political oppression, they hope for a loving and caring Jesus that will liberate them from social-economic difficulties. The teaching of prosperity gospel points the hearers to hope which society do not give them. It seeks to saturate the minds of adherents with the dreams of a better life, whether utopian or practical amid the chaos.

\section{Conclusion}

Today, the notion of prosperity gospel has spread from American prosperity gospel setting and Nigerian Pentecostal milieus to the general body of African Christianity. Prosperity gospel is now advocated in many Christians pulpits in Nigeria. Each time the prosperity gospel is preached, the amalgamated theology which articulates element of American prosperity gospel such as seed faith, positive confession and visualisation, faith healing, giving for a hundred-fold returns and elements of Nigerian Pentecostal revivalism such as exorcism, power of God to subdue satanic forces, victory over demonic agents and divine intervention in human affairs are made manifest.

\section{References}

Achunike HC (2007) Prosperity Preaching in the Nigerian Religious Space. Nigerian Journal of Social Sciences, 4(1): 83-96.

Amechi LA (2014). The Pentecostal Challenge to the concept of Salvation in Liberation Theology. PhD thesis, North-West University, Potchefstroom.

Bowler K (2013) Blessed: a history of the American prosperity gospel. United Kingdom: Oxford University.

Bible, K. J. (1996). King James Bible. Proquest LLC. 
Carr P (2003) Revisiting the protestant ethic and the spirit of capitalism: Understanding the relationship between ethics and enterprise. Journal of Business Ethics, 47(1), 7-16.

Cohen AL; Hellferscee O; Pretorius M; Treurnicht F; Walaza S; Madhi S and Wolter N (2014) Epidemiology of influenza virus types and subtypes in South Africa, 2009-2012. Emerging infectious diseases, 20(7), 1162.

Ehioghae EF and Olanrewaju JA (2015) Theological Evaluation of the Utopian Image of Prosperity Gospel and the African Dilemma. Journal of Humanities and Social Science, 20(8):69.

Folarin GO (2007) Contemporary state of the prosperity gospel in Nigeria. Asia Journal of Theology, 21(1): 69-95.

Folarin GO (2006) Prosperity gospel in Nigeria: a re-examination of the concept, impact, and evaluation. African journal of Biblical studies, 23(2):79-97.

Gaiya MAB (2002) The Pentecostal Revolution in Nigeria. Occasional Paper, Centre for Africa Studies, University of Copenhagen.

Gifford P (1990) Prosperity: A New and Foreign Element in African Christianity. Journal of Religion in Africa, (20): 378-387.

Gutierrez G (1974) A Theology of Liberation, Politics and Salvation. Maryknoll, New York: Orbis.

Ilogu E (1974). Christianity and Ibo culture. Brill Archive.

Isichei E (1995) A history of Christianity in Africa: From antiquity to the present. Michigan: Wm. B. Eerdmans Publishing.

Kalu O (2008) African Pentecostalism: An Introduction. England: Oxford University Press.

Kalu O (2002) Preserving a Worldview: Pentecostalism in the African Maps of the Universe. Pneuma, 24(2):110-137.

Kalu O (2000) Power, Poverty and Prayer: The Challenges of Poverty and Pluralism in African Christianity 1960-1996. Frankfurt: Peter Lang.

Kitause R (2017) A Historical Study of Prosperity Gospel Preaching in Nigeria, 1970-2014. PhD Thesis, University of Nigeria.

Kenyon EW (2004) Signposts on the Road to Success. Lagos: Shepherd Books. 
Kwateng-Yeboah J (2017) A Re-appraisal of the Prosperity Gospel in African NeoPentecostalism. MA Thesis, Queen's University.

Magbadelo JO (2004) Pentecostalism in Nigeria: exploiting or edifying the masses? African Sociological Review/Revue Africaine de Sociologie, 8(2): 15-29.

Maxwell D (1998) Delivered from the Spirit of Poverty? Pentecostalism, Prosperity and Modernity in Zimbabwe. Journal of Religion in Africa, 28(3): 350373.

Nafziger EW (1972) The economic impact of the Nigerian civil war. The Journal of Modern African Studies, 10(2): 223-245.

Ojo MA (2013) Consonance and Dissonance in the Doctrinal Emphasis of Prosperity among Nigerian Pentecostal. African Journal of Pentecostal and Charismatic Studies, 1(1): 9-22.

Okwori EM (1995) Godliness for Gain: An Evaluation of the Nigerian Version of the Prosperity Gospel. Jos: Capro Media Services.

Olofinjana IO (2012) The Story of an Unsung Hero: History and Legacy of Garrick Sokari Braide (1882-1918). [Online] israelolofinjana. Available at: https://israelolofinjana.wordpress.com/2012/01/15/the-story-of-an-unsunghero-history-and-legacy-of-garrick-sokari-braide-1882-1918/ [Accessed 27 January. 2020].

Omavuebe A (2017) The impacts of Pentecostalism on the Anglican Church in Nigeria. MA Thesis, University of Central Lancashire.

Onwu EN (2006) Poverty and Prosperity in Nigerian Pentecostal Theology: A New Testament Critique. Journal of New Testament Research, 1: 1-26.

Oral R (1970) Miracle of Seed-Faith. Oklahoma: Oral Roberts Evangelistic Association.

Oyakhilome C (2019). Rhapsody of Realities. Nigeria: Love World Publishing Limited.

Oyakhilome C (2018) How to make your faith work. Nigeria: Love World Publishing Limited. 
Phillips $A B$ (2013) An examination of the prosperity gospel: a plea for return to biblical truth. PhD thesis, Liberty University Baptist Theological Seminary. Available at: ProQuest.

Pickering JSM (2013) Promises of prosperity according to the Old Testament: a theological-ethical study. MA Thesis, Stellenbosch University. Available at: Stellenbosch University http://scholar.sun.ac.za

Rotimi NC Nwadialor KL and Ugwuja AM (2016) Nigerian Pentecostal churches and their prosperity messages: a safeguard against poverty in Nigeria? 19802014. Journal of African Studies, 5(2).

Szretter KJ; Balish AL and Katz JM (2006) Influenza: propagation, quantification, and storage. Current protocols in microbiology, 3(1), 15G-1.

Turner HW (1967) History of an African Independent Church. England: Oxford University Press. 